\title{
Tax Administration of Large Taxpayers in Some CEE and CIS Countries
}

\author{
Jasna Bogovac, ${ }^{*}$ Natalia Soloveva, ${ }^{* *}$ Michal Radvan, ${ }^{* * *}$ Jarosław Marczak, ${ }^{* * *}$ Natalia \\ Uvarova-Patenko*****
}

* Jasna Bogovac is Associate Professor at the Department of Financial Law and Financial Science at the Faculty of Law, University of Zagreb. She has a $\mathrm{PhD}$ and master's degree in tax law and BA in economy. With 24 years of professional experience in accounting, finance and tax management at departments of multinational companies, and education both in economics and law, she specialised in an interdisciplinary approach to taxation. Her primary areas of expertise are public finance, corporate taxation and tax administration. She is a member of the Institute of Public Administration (Zagreb) and the Centre of Information and Organization of Public Finances and Tax Law Research in Central and Eastern Europe. (e-mail: jbogovac@pravo.hr)

** Natalia Soloveva, PhD in Law, Associate Professor at the Department of International Economics and International Business Activity. The author specialises in taxation, tax systems and tax law. She is the author of a monograph and co-author of 5 books. She has published more than 50 articles in leading legal journals and conference papers in Russia and abroad. The author is a member of the Russian Branch of the International Fiscal Association and the Centre of Information and Organization of Public Finances and Tax Law Research in Central and Eastern Europe. (e-mail: nubiforme@mail.ru)

*** Jarosław Marczak, PhD, Institute of Finance, Faculty of Economics and Sociology, University of Łódź, Poland. He is mainly focused on comparative public finance, finance of local government, fiscal (tax) systems and tax policy. He is a member of the Centre of Information and Organization of Public Finances and Tax Law Research in Central and Eastern Europe. He presented his scientific research in more than 100 articles in Polish, English and Russian in journals and monographies, mainly concerning the Spanish tax system and the regional finance in Spain. (e-mail: marczak. jaroslaw@gmail.com)

${ }^{* * * *}$ Michal Radvan is Vice-Dean for Foreign and External Affairs at the Faculty of Law, Masaryk University, Czech Republic, and Associate Professor of Financial Law at the Department of Financial Law and Economics. He specialises in tax law. He is the author of 5 books and the co-author of almost 40 books. He presented his scientific research in approximately 70 reviewed articles in prestigious journals and conference proceedings. He is a member of the European Association of Tax Law Professors and the Centre of Information and Organization of Public Finances and Tax Law Research in Central and Eastern Europe. (e-mail: michal.radvan@law.muni.cz)

***** Natalya Uvarova-Patenko, PhD in Law, Department of Accounting and Audit at the Caspian University, Associate Professor of the Graduate School "Adilet", Caspian University, Almaty, Republic of Kazakhstan. The author specialises in theory of public administration, public finance and financial law. She is the co-author of 1 book (Theory of Public Administration). She has published more than 50 articles in leading legal and economic journals, monographs and conference papers in Kazakhstan and abroad. (e-mail: uvarova.natalya@yahoo.co)

Abstract: We compare tax administration of large taxpayers in Croatia, the Czech Republic, Russia, Poland and Kazakhstan. Our hypothesis is that these units of tax administrations play an important role in collecting public revenue as well as preventing tax evasion in a dynamic global economy. 
We provide evidences about the most important characteristics of large taxpayer offices, their normative definitions, scope of work and positive as well as negative aspects of their practice. Some data are compared between countries and some for each country separately, due to the fact that differences in the above-mentioned countries, in size, economic and political aspects, vary substantially. Moreover, we were confronted with the limited scope of available information what made our comparison even more challengeable. Therefore, this work is, in a way, a "pioneer" attempt to compare specific national LTOs in one place. Our findings support the discussion that prove the hypothesis and enable recommendations.

Keywords: Large Taxpayers' Office; tax administration; public revenue; Croatia; Russia; Poland; the Czech Republic; Kazakhstan

\section{Introduction}

Experience of many countries in developed economies shows that the creation of specialised control mechanisms over the activities of large taxpayers has led to better tax compliance and increase in the efficiency of tax administrations, including the optimisation of their functions. Existence of special tax units gives tax authorities the opportunity to focus on a relatively small group of taxpayers, which pay a large percentage of all tax revenues. ${ }^{1}$

To date, special units for large taxpayers (hereinafter: Large Taxpayers' Office, LTO) have been created in most OECD countries.

Despite the fact that the tax system is a primarily national economic and legal phenomenon, research of the practice of tax regulation in different countries gives wide opportunities for improving the tax system of a particular state.

The present article offers the analysis of large taxpayers' administration in Croatia, ${ }^{2}$ the Czech Republic, the Russian Federation, Poland and the Republic of Kazakhstan. ${ }^{3}$

Our hypothesis is that LTOs became strategic organizational units for developing countries and their existence is of great importance for tax administrations with the aim to cope with the fast changing global environment.

The paper is structured as follows. As a basis for the determination of similarities and differences of the history and practice of the LTOs in the aforementioned countries, definitions of the large taxpayers' authorities responsible for their administration, positive and negative experiences, as well as data on their roles and responsibilities are presented in Chapter 2. Discussion on the proofs of the hypothesis is given in Chapter 3 which briefly concludes and gives recommendations.

\section{Methods and Data}

With the aim to compare, discuss and make conclusions on the benefits of the existence of the large taxpayers' offices in our countries, their development and possible improvements, we were confronted with two main challenges. 
Firstly, there are the obvious and huge differences in size, population, history and economic realities between them. The environment, social, economic and technological development throughout time and at present of the analysed countries narrowed our research to several aspects that can be rationally compared.

Another challenge which we faced at the very beginning and during our research is the "rather limited" amount of information on operation of Tax Administrations and evidence on their effectiveness. Moreover, there are some documents that we could use as a literature review on the topic, ${ }^{4}$ but information collected and analysed within these projects were limited to the basic explanations and definitions of the LTO, together with explanations and developments of LTOs in countries that are rarely covered with our research. Since we want our paper to contribute to new knowledge in the field, following the previous projects, we decided to continue with the work in a way it would be a combination of the legislative analysis and field research.

There is no accurate data on the revenues generated by large taxpayers, i.e. very little data are available (as is the case with other information in the area of taxation in our countries). Most of the information and attitudes of this paper were based on personal experiences or conversations we had with people employed in tax administrations, or the offices, and with large taxpayers.

For lack of exact data, we have used some available information on the historical development and roles and responsibilities of the respective offices.

To be more precise, these data are probably handled by the Intra-European Organization of Tax Administration (IOTA), but they are only available to some authorised users from each member state, i.e. the tax administration.

The very diversity of the countries we are concerned with, because each scientist presents their specific country situation, causes the absence of an accurate comparison of all the data and conclusions that you are looking for.

However, given the available information, we decided that these offices are important and useful parts of tax administration and that there are some good and some bad experiences that can serve the further advance of developing countries.

Therefore, we proceed our research in two phases. Firstly, we give general information on the definition of the large taxpayers and units of tax administrations which govern them for each country. We stress the main differences between their practice and experiences in contrast to other tax administration units that deal with other taxpayers. To support discussion on the subject matter, we also provide findings on the problems these offices face in their daily operations. Secondly, we collected and arranged data on the development, roles and responsibilities of the LTOs in these countries so that our exploration of the importance of these offices within each State Tax Administration become more transparent and rationalised (Table 1). 


\subsection{Definition of large taxpayers}

\subsubsection{Croatia}

In accordance with the Bylaw on the conditions for the fulfilment of the criteria for the appointment of the large taxpayers under responsibilities of the large taxpayers' office, ${ }^{5}$ one of the following conditions has to be met:

1. Taxes equal or are above HRK $150 \mathrm{~m}$ (approximately Euro $20 \mathrm{~m}$ ).

2. Business activity of:

a) insurance, leasing and telecommunications with revenues above HRK $15 \mathrm{~m}$ (approximately Euro $2 \mathrm{~m}$ ), or

b) banks, regardless of the amount of revenue.

3. Large projects with the expected revenue exceeding HRK $150 \mathrm{~m}$ to which a significant number of taxpayers can be associated (e.g. subcontractors).

In addition to the strict conditions, flexibility of the appointment is assured by the possibility of the Large Taxpayers' Office (e.g. simultaneous controls to be carried out on related persons) to propose to the Director General to issue a decision on the responsibilities of the Large Taxpayers' Office for the taxpayers that do not meet prescribed conditions.

Once a taxpayer is recognised as a "large" one, he/she stays under the responsibility of the LTO for three tax periods. The LTO deals with approximately 650 taxpayers. ${ }^{6}$

\subsubsection{The Czech Republic}

According to Section 11(2) of the Financial Administration Act, large taxpayers are legal entities with turnover higher than CZK 2,000,000,000 (approximately Euro 75 m).

The Specialized Tax Office is a sui generis financial office and has jurisdiction over certain special entities:

- large taxpayers - legal entities with turnover higher than CZK 2,000,000,000 (approximately Euro $75 \mathrm{~m}$ )

- banks and credit unions, including branches of foreign banks

- insurance companies, including branches of foreign insurance companies

- investment funds and their management companies

- pension companies and their funds

- lottery operators

- members of groups according to the Value added tax act

The Specialized Tax Office currently manages taxes on about 1,500 taxpayers. ${ }^{7}$ 


\subsubsection{Russia}

The role of large taxpayers in the formation of the budget of the Russian Federation is constantly increasing. Their share in tax revenues of the state according to different sources ranges from half to two thirds.

There is no definition of large taxpayers in the Tax Code of the Russian Federation. Criteria for recognition of taxpayers as large ones are specified in the Order: ${ }^{8}$

1. Indicators of financial and economic activities for the accounting year according to accounting and tax reporting of taxpayer.

2. Interdependence and influence of the taxpayer on the economic results of activities of associated taxpayers.

3. Special permission (license) for conducting specific activities by taxpayer (banking activity, insurance activity, etc.).

Depending on the value of indicators of financial and economic activities, large taxpayers are divided into two types:

1. Large taxpayers administered at the federal level.

The taxpayer should meet the following indicator: the total sum of received revenues exceeds 35 billion Rubles (approximately Euro 480 m).

In addition, organizations that are subject to tax administration at the federal level include those that do not meet the established criteria, but the Federal Tax Service has decided to classify them as the largest taxpayers.

2. Large taxpayers administered at the regional level (the taxpayer should meet all the following indicators at the same time):

- the total sum of received revenues ranges from 2 to 35 billion Rubles (approximately from Euro $25 \mathrm{~m}$ to Euro $480 \mathrm{~m}$ )

- assets rated from $100 \mathrm{~m}$ Rubles (approximately from Euro $1.25 \mathrm{~m}$ ) or the total amount of federal taxes exceeds 75 m Rubles (approximately Euro $1 \mathrm{~m}$ )

- the average number of employees exceeds 50 persons

The status of large taxpayer is kept for the next three years following the reporting period in which indicators of financial and economic activities no longer meet specified limits.

\subsubsection{Poland}

The tax office and tax chamber act does not provide an explicit definition of a large taxpayer, but its Article 5, item 9c implies that taxpayers should be selected for specialised tax offices based on a value criterion and an industry criterion. The first criterion states that a large taxpayer is an entity with end-of-the fiscal year net revenue amounting to an equivalent of at least Euro $5 \mathrm{~m}$. There are some exceptions to this rule that will be presented below. The criterion is invalid in case of organizations that meet the industry criterion, according to which large taxpayers are: 
1. tax capital groups

2. banks

3. insurance companies

4. organizations conducting business regulated by the act on trade in financial instruments of 2005 and investment funds laws

5. organizations conducting business regulated by the act on the organization and operation of pension funds

6. branches or representative offices of foreign corporations

7. incorporated and unincorporated entities that:

a) At the end of the previous fiscal year had a net income (as defined by accounting regulations) from the sale of goods, products and services amounting to an equivalent of at least Euro $5 \mathrm{~m}$, converted at an average exchange rate of the National Bank of Poland, or

b) being resident entities as defined by the foreign exchange law directly or indirectly participate in the management or control of foreign-based enterprises, or have capital shares in them, or

c) are directly or indirectly managed by a non-resident entity as defined by the foreign exchange law or a non-resident entity has at least $5 \%$ of votes at an assembly of shareholders or a general assembly, or

d) being resident entities as defined by the foreign exchange law directly or indirectly participate in the management or control of a domestic enterprise and a foreign enterprise at the same time, or have capital shares in such enterprises at the same time.

Natural persons are not considered large taxpayers even if their net revenue exceeds the aforementioned amount of Euro $5 \mathrm{~m}$, because Article 5, item $9 \mathrm{~b}$ explicitly limits this category of taxpayers to incorporated entities and unincorporated organizations. General partnerships are excluded for the same reason.

\subsubsection{The Republic of Kazakhstan}

The list of large taxpayers, subject to further monitoring, is approved by the government of Kazakhstan no later than December 25 of the year prior to the year of the enactment of the list. The list includes the first 300 large taxpayers with the highest aggregate annual income (without including the adjustment provided for in Article 99 of the Tax Code of the Republic of Kazakhstan). ${ }^{9}$ A taxpayer is considered large on condition that the total book value of all assets is not less than the 325,000-fold monthly calculation index provided for in the Budget Code of the Republic of Kazakhstan, and the number of employees is 250 or more. The approved list of large taxpayers is effective for two years from the date of enactment and is not subject to revision during this period. toring:

The following methods are used to compile a list of large taxpayers, subject to moni- 
a) estimating the aggregate annual income based on the corporation income tax return data for the tax period prior to the year of the approval of the list of large taxpayers;

b) estimating the book value of assets based on the annual financial report data for the year prior to the year of the approval of the list of large taxpayers;

c) estimating the number of employees based on the personal income tax return and social tax deduction data for the last month of the first quarter of the year prior to the year of the approval of the list of large taxpayers.

The monitoring of large taxpayers involves the analysis of their financial and operating performance with the purpose of determining their actual tax base, control of compliance with the Republic's tax regulations, and the market prices employed in transfer pricing. Large taxpayers should submit an account of monitoring in the form of an electronic document certified by a digital signature. An account of monitoring includes a balance sheet, reports on the goods manufactured and purchased, work done and services rendered; costs of goods manufactured, work done, and services rendered; a report on the financial and operating performance; and an explanation of accounts receivable and accounts payable.

\subsection{Authorities responsible for the administration of large taxpayers}

\subsubsection{Croatia}

The Croatian Tax Administration organization consists of three parts: Central Office, Regional offices (six being responsible for regions and one Large Taxpayers' Office at the national level) and 57 branches on the local level (in towns and municipalities, subordinated to regional offices). Its headquarters are in Zagreb, supported by three dislocated units in Osijek, Rijeka and Split. The total number of officials in the LTO is $112 .^{10}$

Historically, LTO in Croatia have been developed from the unit responsible for the audit and collection of taxes from the largest companies, with the continuous and logical evolution resulting in an office for the sophisticated approach to the large taxpayers on a daily basis, as well as for its audit. Chronologically, the most important phases were the following:

- 2003: The Unit for Large Taxpayers' Audit have been established within the Zagreb Regional Office. ${ }^{11}$

- 2009: Establishment of the two units for large taxpayers: Office for Large Taxpayers' Audit and the separate Zagreb Branch for Large Taxpayers, ${ }^{12}$ both within the regional office in Zagreb. ${ }^{13}$

- 2012: Establishment of the Large Taxpayers' Office in Zagreb with three branches (dislocated units) in Split, Rijeka and Osijek. ${ }^{14}$ The LTO integrates the work of the audit and the daily collection of taxes for large taxpayers. ${ }^{15}$ More than 600 large taxpayers were identified with the share of the $46 \%$ of all taxes and contributions paid to the budget in 2011. Thus, in addition to 20 regional offices in Croatia, 
the separate $21^{\text {st }}$ office was established with "specific internal organization" that is necessary for such assignments. The Large Taxpayers' Office with headquarters in Zagreb was responsible for all large taxpayers in Croatia.

- 2014: Decrease in the number of regional offices, ${ }^{16}$ but LTO remains one of the crucial organizational units within the Croatian Tax Administration, being one of the seven "regional offices" (see supra). Roles and responsibilities of the office have not change in comparison to the 2012 Decree, hence the continuity in work.

The LTO employees are engaged as team members in the cooperation with colleagues from different departments and the Central Office. The internal and external cooperation of the LTO employees with the public officials in other institutions (e.g. Croatian National Bank, Croatian Financial Services Supervisory Agency), and thematic meetings with the private sector stakeholders, show their willingness to cooperate in line with the values and ethical principles stated in the Strategy of the Tax Administration ${ }^{17}$ and to overcome the traditional vertical and horizontal fragmentation in public administration in Croatia. ${ }^{18}$

The LTO staff is provided with "special training courses in order to acquire the specific knowledge and skills and apply the modern techniques required for tax audit and desk audit, including risk analysis". ${ }^{19}$ This task is closely connected with the following aspect.

They achieve international cooperation with the EU, OECD, IOTA, IMF and the World Bank, as well as bilaterally, in the fields of risk management, audit, procedures and techniques, and IT. Various projects, pilot-projects, funds, seminars, workshops and exchange of employees with Member States strongly supported the employees' and the management's skill development.

\subsubsection{The Czech Republic}

As mentioned in previous research papers, ${ }^{20}$ tax administration in the Czech Republic is divided between Financial Administration of the Czech Republic and Customs Administration of the Czech Republic. Tax administration sensu lato is also carried out by municipal offices (local and administration charges), other offices (administration charges) and courts (court fees). This division of tax administration has existed de facto since 2004 when the Czech Republic joined the EU. Then it was decided that the bodies of Customs Administration would be in charge of the administration of selected excise taxes and VAT on imports. As for Financial Administration, until 2012, there were financial offices as first-instance bodies, financial directorates as second-instance bodies and the Ministry of Finance with an internal organizational unit - Central Tax and Finance Directorate. The General Financial Directorate, which was established in 2011, was followed by the Specialized Tax Office, which was introduced just a year later. The new Act no. 546/2011 Sb., on Financial Administration of the Czech Republic (Financial Administration Act) took over, to a certain extent, these existing institutions so that a logical and properly arranged three-instance system of bodies of Financial Administration of the Czech Republic could be launched as of 1 January 2013. The establishment of the system of the Financial Administration bodies brought mainly a unified central control of a system of 
bodies which, despite being formally subordinated to the Ministry of Finance, are de facto managed by the General Financial Directorate with general jurisdiction. The newly established Financial Administration meets the parameters of a possible future system of bodies called JIM (jedno inkasni misto, i.e. single collection place) so that the Financial Administration could, if given more power, continue without having to change its structure.

The General Financial Directorate's function is mainly directive and methodological in the field of tax administration. The directorate closely cooperates with the Ministry of Finance in the legislative, analytic and conception activities and in the area of international relationships (international administrative cooperation and recovering financial receivables). The appellate financial directory is an administrative body directly superior to financial offices. It also deals with administrative offences and it also acts as a contact body for the agenda of recovering some receivables. As for the area of international cooperation in tax administration, it administers the records and registries needed for operation of the Financial Administration bodies. At the basic level, there are fourteen financial offices, i.e. one for each region and one office for Prague. Aside from them, there is a Specialized Tax Office (not only) for large taxpayers. Financial offices have local offices, usually in the place where the original financial offices had been prior to the reform of 2013. As for the subjectmatter jurisdiction, financial offices carry out almost all powers granted to the bodies of Financial Administration; they are especially in charge of the administration of taxes at the first instance. ${ }^{21}$

The Specialized Tax Office represents tax administration on the national level. The seat of the Specialized Tax Office is Prague, but it has several regional offices (Plzeň, Hradec Králové, Ústí nad Labem, Brno, Ostrava a České Budějovice). The Director of the Specialized Tax Office is appointed and removed by the Director General of the General Financial Directorate. The Specialized Tax Office provides the following activities: ${ }^{22}$

- performs the administration of taxes, with the exemption of immovable property tax and immovable property transfer tax, and administrative, court and local charges/fees

- carries out the proceedings about administrative offences

- transfers collected tax incomes

- performs supervision over lotteries and other gambling games

- collects and enforces pecuniary compliance imposed by them

- keeps records and registers, which are needed for the performance of activity of the financial administration bodies

- performs financial control

- performs investigations according to the Accounting Act and imposes fines

- under the authorisation of the Ministry of Finance, it fulfils a role of Liaison Office for the recovery of financial claims and provide international assistance in the administration of taxes

- under the authorisation of the Ministry of Finance, it reviews the economy of Regions, the Capital of Prague and regional councils of regions cohesiveness and performs a supervision over the reviewing of economy of municipalities, voluntary associations of municipalities and the city districts of the Capital of Prague 


\subsubsection{Russia}

On the basis of levels of state administration and administrative-territorial division of the Russian Federation, the structure of the tax authorities in Russia consists of four levels:

- federal level that is the Federal Tax Service of Russia

- federal-regional level - interregional inspections of the federal districts

- regional level - tax administrations of the subjects of the Russian Federation

- local level - tax inspections that is the lowest unit of tax authorities' system

The structure of the tax authorities also includes specialised interregional inspections (federal level) and specialised interdistrict inspections (regional level).

The system of tax administration of large taxpayers in Russia appeared in 2001. Nowadays administration of large taxpayers at the federal level is implemented by interregional inspections for large taxpayers. At the moment there are nine interregional inspections for large taxpayers that are specialised by industrial principle: oil; gas; manufacturing industries, construction and trade; electric power industry; metallurgical industry; transport services; telecommunication services; military-industrial complex; banks and insurance companies. $^{23}$

At the regional level large taxpayers are administrated by interdistrict inspections for large taxpayers. Interdistrict inspections are created in the structure of tax administrations of the subjects of the Russian Federation. In case if such interdistrict inspections are not created in certain tax administrations, large taxpayers are administrated by the tax inspection at the location of originations but control over their administration are implemented by tax administrations of the subjects of the Russian Federation.

\subsubsection{Poland}

Until the end of 2003, all taxpayers in Poland regardless of their size were handled by tax offices with jurisdiction over the taxpayer's place of residence, registered address or registered business address. However, complicated relations between domestic and foreign companies, Polish and international capital groups, raised many doubts as to the reliability of their tax settlements. Phenomena such as transfer prices and tax optimisation schemes emerged, which had never or rarely been observed before. The situation was aggravated by the high turnover of the tax office staff, insufficient training of the staff in dealing with taxpayers assisted by large consultancies, and, quite frequently, by confirmed suspicions that taxpayers were trying to evade the payment of taxes. As a result, the tax office act was amended and 20 Specialised Tax Offices (STOs) were appointed to exclusively handle large taxpayers from 1 January 2004. The new approach has not solved problems related to the operations of large taxpayers, though.

STOs have the single purpose of handling large taxpayers. As mentioned, twenty STOs have been selected to provide service to large taxpayers, i.e. four more than there are voivodeships in the country. These additional STOs are based in the Mazowieckie Voivodeship (2) and in the Silesian and Wielkopolskie Voivodeships (1 extra in each). They were 
created because of significant numbers of large taxpayers in these voivodeships and the need to provide high-quality service. STOs operate on the same rules as other tax offices do. The highest number of large taxpayers is registered in the Mazowieckie Voivodeship, particularly in the capital city of Warsaw. Research shows that of 96,903 large taxpayers that Poland had in 2013 approximately 45,659 (ca. 38.5\%) were based in that voivodeship. ${ }^{24}$ It must be noted, however, that some taxpayers are not active, meaning that not all of them pay corporate income tax (CIT). In 2013, only 52,960 taxpayers (ca. $55.5 \%$ ) filed CIT-8 returns. 14,013 taxpayers (ca. $26.4 \%$ of the active ones) reported net revenue in excess of the equivalent of Euro $5 \mathrm{~m}$.

On 1 January 2016, the Tax Administration Act establishing the National Specialised Tax Office (physically, the $1^{\text {st }}$ Mazowiecki Tax Office in Warsaw) for taxpayers with net revenue exceeding the equivalent of Euro $50 \mathrm{~m}$ (their number was estimated at ca. 3,830, of which around 1,000 had already been serviced by that tax office) was to enter into effect. ${ }^{25}$ However, it did not become effective until 1 July 2016, because of the plan to reform the tax, treasury and customs administration (by establishing the National Treasury Administration).

\subsubsection{The Republic of Kazakhstan}

Tax administration involves tax control by taxation bodies, implementation of methods that would ensure the fulfilment of overdue tax obligations, tax enforcement and provision of public services to taxpayers (tax agents) and other authorised public bodies according to the established procedure. A first mention of the responsible body for the large taxpayers was prescribed in 1999. ${ }^{26}$ Tax administration on the national scale, as well as tax administration of large taxpayers is performed by the State Revenue Committee of the Ministry of Finance of the Republic of Kazakhstan. ${ }^{27}$ The monitoring of large taxpayers is performed by analysis of financial and economic activity of large taxpayers in order to determine their actual tax base, control of compliance with tax legislation of the Republic of Kazakhstan and the applicable market prices in order to monitor transfer pricing. During the monitoring, the authority may demand from the large taxpayers subject to monitoring, submission of documents confirming the correctness of tax calculation and timely payment of taxes and other obligatory payments to the budget and financial statements of the taxpayer (tax agent), including financial statements of its subsidiaries.

\subsection{Positive aspects of the LTOs practice}

\subsubsection{Croatia}

The Large Taxpayers' Office consolidates the largest Croatian taxpayers from different sectors (industry, trade, banking, insurance) and theirs related companies. The work scope requires of the LTO officials a good education and knowledge about the international and Croatian accounting standards, taxation, IT, law and economics, the same as to be familiar 
with the taxpayers' business environment. Covering both direct and indirect taxes, enabling a focus to the "whole of taxpayer" within the administrative taxpayers' affairs, the LTO staff is dedicated to broaden a close relation with the taxpayers with complex and considerable transactions. Audit of the transfer prices and thin-capitalisations are at the top of the tax issues in the EU and globalised world, the same in complexity as in the amounts. Therefore, it is crucial that the LTO employees work in teams, exchange information and continuously learn and develop professional skills. While these issues are advisable for other public officials, for the LTO officials they are indispensable.

The LTO in Croatia is recognised as a strategically important unit since the conducting audit "is the most important aspect of the overall control function of the Tax Administration" ${ }^{28}$ at the same time being involved in cooperation with the large taxpayers that "deserve special status and services. [...] Tax Administration will continue to develop services and a special way of communication with large taxpayers". ${ }^{29}$

The development of special skills and knowledge of the LTO staff can be recognised in the way they deal with the largest taxpayers in the country. They apply:

- an individual approach to each taxpayer

- team work and open communication within the headquarters in Zagreb, as well as with the employees in regional offices dedicated to the large taxpayers; the Head of the LTO participates in the daily work and communication, giving additional support to the staff

- acting in real time and up-front, increasing openness and dialogue with taxpayers in order to prevent the problems as they occur; this approach is supported by a legal basis that gives opportunity to the Tax Administration and taxpayers to cooperate with the aim to decrease tax risks on both sides (horizontal monitoring) ${ }^{30}$ as well as the number of audits and disputes (voluntary adjustments of the submitted tax returns $)^{31}$

Due to the incremental development of the Large Taxpayers' Office, which modestly began in the early 2000s, Croatia now has a national office that can be recognised as a centre of excellence within the Tax Administration. Its employees are involved in many national and international projects, contributing to working groups by their knowledge and experiences from a complex and sophisticated field. Their work is also recognised by the taxpayers who expressed their trust and reliability in this office. ${ }^{32}$ Continuous development of their partnership with the largest taxpayers in the country forms a basis for further development and importantly contribute to the improvement of the whole Croatian Tax Administration organization. ${ }^{33}$

\subsubsection{The Czech Republic}

Generally, there are no differences between the large taxpayers' administration by the Specialized Tax Office and administration of all other taxpayers by "normal" tax offices. The essential difference lies in the extent of territorial jurisdiction: the Specialized Tax Office's territorial scope is nationwide. For the purposes of tax administration by the 
Specialized Tax Office so called sectoral breakdown of selected entities is accentuated. Tax administration is performed by the team of specialists for specific sectors, always with respect to the operating conditions of a particular industry in which the selected entity carries out its activities.

The main benefit of a team tax administration is to obtain a comprehensive insight into the activities of the tax entity or to the activities of the group of entities. The working team shares any information about this group, so there is no loss, fragmentation or omission. A prerequisite for a team tax administration is constant communication among all staff members, information sharing and joint solution of problems. ${ }^{34}$

In February 2015, the Specialized Tax Office initiated a controlling operation in order to verify the correctness of setting the transfer pricing between companies that are personnel or property related. The main aim of the operation was to prevent possible tax evasion. The tax entities were chosen for control due to the analysis of data gained from questionnaire voluntary filled in by tax entities last year and from data obtained by searching activities of the Specialized Tax Office. ${ }^{35}$

The Specialized Tax Office has its Price Control Unit. Controls are focused on the compliance of the way of price regulations set by the Price Act and further on assessment whether in the area of non-regulated prices did not occur an abuse of economic position. State control over betting games and lotteries is another area of the Specialized Tax Office's competencies. This state control is performed by employees of the State Control and it is focused on compliance with the Lotteries Act and conditions resulting from the permissions to run lotteries and other like games. ${ }^{36}$

\subsubsection{Russia}

The practice of tax administration considers the following features that are inherent to large taxpayers:

- maintenance activities on large territories belonging to different regions of the Russian Federation

- extensive organizational and management structure

- broad participation in the processes of international integration and cooperation

Organizational and regulatory support of administration of large taxpayers is exercised on the basis of general provisions of the Tax Code of the Russian Federation. However, the specificity of tax administration of this category of taxpayers is determined in the different regulations (orders, instructions, methodical guidelines) of the Ministry of Finances of Russia and the Federal Tax Service.

Thus, there are detailed rules of registrations of large taxpayers that provide procedures and time limits different from the general rules. ${ }^{37}$

There are also some peculiarities of tax reporting; however, they are caused by the presence of special subjects (interregional and interdistrict inspections) of tax control.

At the same time, tax control over activities of large taxpayers is provided in the form of tax audits, which are carried out according to the general rules fixed in the Tax Code. 
Thus, it is fair to say that generally, the tax administration of large taxpayers is only slightly different from the tax administration of other legal entities.

As it was mentioned with regards to considering countries, the main advantage of the tax administration of large taxpayers namely by specialised tax units is their focus on working only with this category of taxpayers. As a result, there are the following positive trends:

- improving of efficiency of tax administration

- cost optimisation of tax authorities for implementation of tax control measures

- improving of tax compliance of large taxpayers

\subsubsection{Poland}

The establishment of specialised tax offices for taxpayers provided an opportunity for staffing them with very competent workers, capable of making reliable assessments of taxpayers' real and legal situation and of being their partners in tax settlement processes. Because of the complexity of large organizations' business relations, the control bodies must have the appropriate knowledge to resolve a considerable proportion of disputable situations without involving the court.

\subsubsection{The Republic of Kazakhstan}

Kazakhstan takes drastic measures to improve tax administration. The implementation of a tax administration improvement program in 2010-2011 took the Republic's tax system to a brand new level of quality, providing convergence with international practices. Over 50 amendments dealing with issues of tax administration have been made to the Tax Code of the Republic of Kazakhstan. The process of improving the legal mechanisms of tax administration in terms of combating tax evasion is ongoing. This pertains to large taxpayers, as well.

\subsection{Problems the administration of large taxpayers are facing}

\subsubsection{Croatia}

The positive practice and experiences gathered during the 13 years of existence of the Croatian Tax Administration team of large taxpayers need to be used and fatherly developed especially with regards to the following:

1. Staffing the team with experts from the fields of accounting, finance, corporate, financial and intellectual property law, international tax law and IT, is a necessity to keep the pace with the large taxpayers, both in terms of the daily cooperation and of their audit. 
2. Even though the notion of support to the work of the LTO is continuously repeated in strategic documents and can be easily recognised within the organizational hierarchy (see supra), the encouragement is sometimes missed. It must be taken into consideration that Croatia does not provide a business-friendly environment $^{38}$ and that the work of the LTO staff is sometimes not recognised on behalf of other public officials or by the general public, which may cause obstacles in their daily work.

3. Officials of the Large Taxpayers' Office are often being hindered in their work with a variety of denunciations from other state entities that have no particular connection with their work and responsibilities, and it often turns out that it does not have a great material significance, either.

\subsubsection{The Czech Republic}

As the above mentioned benefits of the existence of the Specialized Tax Office prevail, not every taxpayer or selected entity is satisfied, especially those from smaller cities. Mostly till the end of 2011, such a selected entity was usually (one of) the largest taxpayers in the territorial jurisdiction of a tax office and it had an "eminent position". Not in the sense of lower taxes, of course, but the tax office was ready to help, give advice, cooperate, as the main purpose of the tax administration is to assess taxes right (the correct amount, on time). Nowadays such a selected entity is one of many similar selected entities and it has no longer the privileges it had before.

\subsubsection{Russia}

Despite the 15 years of existence of the system of large taxpayers' administration by special tax bodies and its positive aspects, there are negative sides of such a system and challenges for its improvement.

Neither the concept of large taxpayers and their criteria, nor the specificity of the administration of large taxpayers is fixed in the Tax Code of the Russian Federation. Regulations of the Ministry of Finances of Russia and the Federal Tax Service that regulate legal relations on large taxpayers' administration are often changed. Moreover, interregional and interdistrict inspections frequently interpret norms differently. It is necessary to fix in the Tax Code the following: the concept of large taxpayers, the criteria for recognition of organizations as large taxpayers, the rights and obligations of tax authorities and large taxpayers in the implementation of large taxpayers' administration, other provisions that differ from the general procedure of tax administration.

Negative moments of large taxpayers' administration include complication of the system of tax payments' accounting by authorised bodies and increase of errors in this field, as well as the duplication of tax inspections' functions.

For a significant number of large taxpayers administrated at federal level, there is a problem of distance from the place of actual location and conducting business to the 
interregional inspection where such taxpayers are registered as most of the interregional inspections are situated in Moscow. Considerable distance causes additional costs for large taxpayers.

\subsubsection{Poland}

After a decade of the STO's activity, a conclusion was reached that its scope was too broad. "Since the very onset of their activity, specialised tax offices have been handling, according to their designation laid out in Article 5 item $9 \mathrm{~b}$ of the Tax Offices and Tax Chambers Act of 21 June 1996, the same catalogue of enterprises. Their structure, defined following the general organizational model of tax offices, has not changed, either. It lacks systemic solutions accounting for the special needs of taxpayers for which STOs were established. Moreover, the general model of relations with taxpayers takes little account of the fact that the STOs' clients are entities of strategic importance for the development of the national economy, so they need to be approached on an individual basis." ${ }^{39}$ Instead of concentrating on strategic enterprises conducting complicated business operations at home and abroad, STOs handled all active taxpayers indicated in the act, including those with small business volumes. As a result, they were less effective than they could be, as well as less competent and friendly to taxpayers. The findings led to changes in the manner of operation of the STOs, and to the redefinition of a large taxpayer.

\subsubsection{The Republic of Kazakbstan}

General problems of tax administration in Kazakhstan are substantially topical for large taxpayers. The tax administration in Kazakhstan needs to be drastically improved so that it would contribute to the modernization and diversification of the economy, fight against violations of tax regulations and tax evasion, and withdrawal of operating business structures that serve as sources of income for the budget from the shadow sector. According to the Accounts Committee, tax control measures adopted by the public taxation bodies to react promptly to the cases of tax evasion are not effective enough. Taxation bodies often fail to document violations of tax regulations during audit, which is detrimental to the budget of the Republic. Credit resources are often misallocated. There are no approved norms for prices on work and services rendered. Agreement terms are not met, which leads to delays in public purchases and, ultimately, to the failure to achieve direct and end results from the use of intended transfers. ${ }^{40}$

Low quality of the services rendered by the tax administration results in the violation of rights and legitimate interests of all taxpayers including large ones. Thus, in 2014, the Association of Taxpayers of Kazakhstan examined the complaints of taxpayers about the actions of taxation bodies during tax administration. The examination revealed the following problems: lengthy tax audits; unsatisfactory qualification of tax auditors; lack of transparency of tax audits. 
The issue of the implementation of $E$-audit instead of (or along with) the conventional tax control requires thorough examination. The use of E-audit would allow identifying, suppressing, and punishing tax violations. It is recommended by the OECD and is widely used in foreign practices. The same is true for the incorporation of the General AntiAvoidance Rule into the national tax legislation.

The Strategy for the development of Kazakhstan until the year 2050 makes provisions for the introduction of favourable tax treatment for the objects of taxation involved in the production and advanced technologies. It also aims to continue the policy of liberalisation of tax administration and systematisation of customs administration. At the business level, the tax policy should stimulate internal growth and national export to foreign markets and be socially-oriented. Meanwhile, at the level of population, it should stimulate savings and investments. All these strategic tasks provide substance to the long-term public tax policy.

\subsection{Some facts on the growth of the LTOs}

With the aim to compare relevant information of the LTOs, we tried to emphasise some facts that are possible to be collected, and to show them in a way as much transparent as possible. On the other hand, we tried to find information that will show growth in importance of the LTO in every country, since comparison between countries will not be rational. Therefore, some data should be compared between countries and some for each country separately.

Table 1.

Growth, roles and responsibilities of the LTOs (by country)

\begin{tabular}{|c|c|c|c|c|c|}
\hline & Croatia & Russia & Poland & $\begin{array}{l}\text { The Czech } \\
\text { Republic }\end{array}$ & Kazakhstan \\
\hline Year of establishment & $2003^{41}$ & 2001 & 2004 & 2012 & 1999 \\
\hline $\begin{array}{l}\text { Number of employees at the first } \\
\text { establishment }\end{array}$ & 15 & $\mathrm{n} / \mathrm{a}$ & 2,639 & 137 & $\mathrm{n} / \mathrm{a}$ \\
\hline $\begin{array}{l}\text { Number of entities administrated at } \\
\text { the first establishment }\end{array}$ & 1,100 & $\mathrm{n} / \mathrm{a}$ & & 990 & 220 \\
\hline Number of employees (2015-2016) & $136^{42}$ & $\mathrm{n} / \mathrm{a}$ & 2,300 & 460 & $\mathrm{n} / \mathrm{a}$ \\
\hline $\begin{array}{l}\text { Number of entities administrated } \\
(2015-2016)\end{array}$ & 650 & $\mathrm{n} / \mathrm{a}$ & $53,000^{43}$ & 1,500 & 300 \\
\hline Position of the office within the TA & $\begin{array}{l}\text { State } \\
\text { level }\end{array}$ & $\begin{array}{c}\text { From } \\
\text { federal to } \\
\text { local }\end{array}$ & Regional & State level & State level \\
\hline \multicolumn{6}{|l|}{ Responsibilities: } \\
\hline direct taxes & Yes & Yes & Yes $^{44}$ & Yes & Yes \\
\hline indirect taxes & Yes & Yes & Yes $^{42}$ & Yes & Yes \\
\hline contributions (for the employees) & Yes & $\mathrm{No}^{45}$ & Yes & Yes & Yes \\
\hline
\end{tabular}




\begin{tabular}{|c|c|c|c|c|c|}
\hline & Croatia & Russia & Poland & $\begin{array}{c}\text { The Czech } \\
\text { Republic }\end{array}$ & Kazakhstan \\
\hline $\begin{array}{c}\text { coordination with foreign revenue } \\
\text { bodies (e.g. simultaneous tax } \\
\text { audits, exchange of information) }\end{array}$ & Yes & Yes & Yes & Yes & Yes \\
\hline tax compliance of the LT & Yes & Yes & Yes & Yes & Yes \\
\hline tax control of the LT & Yes & Yes & Yes & Yes & Yes \\
\hline $\begin{array}{l}\text { Teams dedicated for specific/ } \\
\text { important/key sectors and industries }\end{array}$ & Yes & Yes & No ${ }^{46}$ & Yes & $\mathrm{n} / \mathrm{a}$ \\
\hline $\begin{array}{l}\text { Employees dedicated for every large } \\
\text { taxpayer; contact-persons for large } \\
\text { taxpayers (compliance, contacts) }\end{array}$ & Yes & Yes & Yes & Yes & $\mathrm{n} / \mathrm{a}$ \\
\hline $\begin{array}{l}\text { Employees participate in strategic } \\
\text { projects (working groups, pilot- } \\
\text { projects or similar decision-making } \\
\text { processes } \text { etc. of the Ministry or } \\
\text { Central Tax Administration Office) }\end{array}$ & $\begin{array}{l}\text { Almost } \\
\text { always }\end{array}$ & Often & $\begin{array}{c}\text { Almost } \\
\text { never }\end{array}$ & $\begin{array}{c}\text { Almost } \\
\text { always }\end{array}$ & $\begin{array}{c}\text { Almost } \\
\text { always }\end{array}$ \\
\hline
\end{tabular}

Source: Compiled by the authors.

Data shows that, where available, very similar facts can be found in the scope of the responsibilities of the LTOs, their teams and employees dedicated to the specific taxpayers and their industry. Also, in the majority of cases, these offices are of strategic importance for the tax administrations, due to the fact that they are established at the state (federal) level and their employees participate in strategic projects of the Ministry of Finance or Central Tax Administrations. Some opposite conclusions can be found in case of Poland, which has LTOs established on regional level and their employees do not participate in strategic projects. Huge and surprising fact is that Polish LTOs deal with 97,000 taxpayers $(53,000$ active legal persons) but the number of employees decreased in the 12 years of the existence of the Office. It is contrary to the practice of modern tax administrations and cannot be justified by any of the basic arguments of the establishment of such a unit. Instead, Poland chooses the establishment of the Large Taxpayers' Office who actually deals with the thousands of medium and small legal entities. On the other hand, the facts show (where available) that LTOs in other countries grow in size (number of employees); this can be a good sign of the recognition of its benefits for the tax administration in general.

\section{Discussion and Conclusions}

Each country has a vastly different tax system, their own economic realities and different experiences of large taxpayers' administration and the analysis shows that although each country uses different approaches to organizing the administration of large taxpayers, benefits obtained and problems they face are rather comparable. 
Therefore, we compared the history and practice of every large taxpayer staff in each country aiming to make conclusions of its advantages and disadvantages, as well as to compare it between the countries in scope.

In all analysed countries, criteria for recognition of legal entities as large taxpayers can be conditionally divided into two groups:

- economic and financial criteria (turnover, amount of taxes paid, revenues received, value of assets, etc.)

- organizational criteria (type of activity, license for conducting certain type of activity, number of employees, interdependence of taxpayers, etc.)

The mentioned criteria may be applied for certain categories of taxpayers both separately and collectively.

In all studied countries, except Kazakhstan, special units of tax authorities for administration of large taxpayers have been created:

- The Large Taxpayer Office in Croatia

- Specialized Tax Office (not only) for large taxpayers in the Czech Republic

- Interregional tax inspections (federal level) and interdistrict tax inspections (regional level) in Russia

- Specialised Tax Offices in Poland

In the Republic of Kazakhstan, the State Revenue Committee of the Ministry of Finance of the Republic of Kazakhstan performs the administration of large taxpayers.

The lack of significant differences in the administration of large taxpayers compared with the administration of all other legal entities is emphasised. The differences are largely due to the presence of the special subject of administration, that is a special unit of tax authorities (for instance, special rules of registration as large taxpayer, etc.).

Among the positive sides of administration of large taxpayers by specialised tax units, the following are marked:

- comprehensive insight into the activities of large taxpayers, as well as an individual approach to each taxpayer

- higher competence of the employees of specialised tax units responsible for large taxpayers' administration

- improving of efficiency of tax administration and tax compliance of large taxpayers

- cost optimisation of tax authorities for implementation of tax control measures

Although the above-mentioned benefits are achieved in different countries to varying degrees, these benefits are undoubtedly important objectives of large taxpayers' administration.

It should be noted that the large taxpayers' administration in different countries has a number of disadvantages, among which are the following:

- the problem of distance from the place of actual location and conducting business to the specialised tax unit where large taxpayers are administrated which, in particular, causes additional costs for taxpayers (the Czech Republic, Russia) 
- the lack of systemic solutions accounting for the special needs of taxpayers for which LTOs were established; being less effective than LTOs could be, as well as less competent and friendly to taxpayers (Poland)

- the lack of legal regulation of large taxpayers' administration at the federal level (Russia)

- some lack of the encouragement for LTO's work, a variety of denunciations from other state entities that have no particular connection with the LTO's work (Croatia)

- the absence of the separate large taxpayers' unit(s) for their administration and control (Kazakhstan)

Nevertheless, it appears that the work of specialised tax units for large taxpayers represents an effective mechanism of tax administration, which over time will be evolving and improving in the interests of the state, as well as taxpayers.

Having in mind all these benefits of the practice of the LTOs, we can conclude that our hypothesis is proven to a great degree, due to the fact that such organizational units grow in roles and responsibilities, as well as in the importance for every tax administration where they are established. The special skills, teamwork and understanding of the big business in a globalised world, makes public servants in those specialised units capable for challenges that tax administrations and taxpayers face regarding tax collection, legal tax certainty, tax evasion and administrative cooperation. Since large taxpayers usually account for the majority of the tax revenue, their existence and improvement in the operations might hugely increase efficiency and effectiveness of the tax administrations in general.

If we give respect to the disadvantages of the practice of LTOs in respectable countries, we can conclude that our hypothesis is not discredited, giving the fact that tax administrations in developing countries faces considerable problems in keeping on track with the practice of modern states. Therefore, some of the issues that create difficulties for achieving its full success can be expected as inevitable problems that can be solved with the help of the experiences of other countries. Kazakhstan, as the only country between the analysed states that failed to establish a separate LTO, can learn from the practice of the developing countries that experienced the benefits of such organizational units. Poland, on the other hand, might learn the most from its own misconceptions. Due to the fact that tax administrations around the globe, in developed and developing countries, are not immune to the problems in organization, effectiveness or "complifications", we think that our findings can be useful for many of them. However, we look forward to see improvements of these offices in our countries. 


\section{References}

1 The majority of the public revenues are collected by the large taxpayers, which is often interpreted in accordance with the Pareto principle. In this article we recognise the significance of this group of taxpayers in the sense of its total taxes (as well as contributions where appropriate) paid in absolute amounts. Our intention was not to interpret the progressivity or redistribution effect of the tax system.

2 Some of the data presented in this article regarding Croatia are parts of the project of the Faculty of Law in Zagreb.

3 This chapter provides legal basis, international organizations' and scientific observations and, where necessary, anecdotal evidences from personal interviews, experiences and surveys of the authors. Each author analysed the tax administration in their own country.

4 Large taxpayers are mostly addressed by the OECD and the IMF, but non of their reports have exact data on the amounts surveyed by these offices, the data are not structured in a way to enable identifying this issues; instead, we have used the data from reports made by the experts coming from these respective organizations and used the results as a basis for their further research. See, for example: OECD (2015) Tax Administration 2015: Comparative Information on OECD and other Advanced and Emerging Economies, or OECD (2010) Forum on Tax Administration, Tax Administration in OECD and Selected Non-OECD Countries: Comparative Information Series.

5 Official Gazette, 67/2015.

6 OECD (2015: 93) evidenced 680 taxpayers, Tax Administration 2015: Comparative Information on OECD and Other Advanced and Emerging Economies, www.oecd.org/ctp/administration/taxadministration-23077727.htm (accessed 15 February 2016).

7 www.financnisprava.cz/cs/financni-sprava/organy-financni-spravy/specializovany-financni-urad/ informace-o-sfu (accessed 09 May 2016).

8 Order of Federal Tax Service of Russia № MM-3-06/308@ dated 16 May 2007.

9 Code of the Republic of Kazakhstan dated December 10, 2008 No. 99-IV On taxes and other obligatory payments to the budget (Tax Code), http://adilet.zan.kz/rus/docs/K080000099_ (accessed 28 April 2016).

10 See OECD (2015: 93), Tax Administration 2015: Comparative Information on OECD and Other Advanced and Emerging Economies, www.oecd.org/ctp/administration/tax-administration-23077727. htm (accessed 15 February 2016).

11 Pursuant to the Decree on internal organization of the Ministry of Finance (Official Gazette, 71/2003).

12 Usually positioned in local branches according to the territorial and functional organization.

13 Decree on internal organization of the Ministry of Finance (Official Gazette, 29/2009).

14 Official Gazzete, 124/2012.

15 In accordance with the Draft Amendments to the Tax Administration Law with final proposal of the Law, the establishment of the Large Taxpayers' Office was one of the strategic goals of the project of the modernization of the Tax Administration (Revenue Administration Modernization Program - RAMP), https://vlada.gov.hr/UserDocsImages//Sjednice/Arhiva//03851.\%20-\%202.pdf (accessed 15 February 2017).

16 Decree on internal organization of the Ministry of Finance (Official Gazette, 154/2014).

17 CTA (2016: 4).

18 Ibid. 71.

19 The CTA Strategy (2011:20).

20 Michal Radvan, Petr Mrkývka, Czech Republic (National report for the conference The Transformation of Tax Systems in the Central and Eastern European Countries [CEE] and BRICS Countries - 25 Years of Experience and Future Challenges.)

21 Ibid.

22 www.financnisprava.cz/en/financial-administration/financial-administration-bodies/specialized-taxoffice/characteristic (accessed 8 May 2017). 
23 Official site of the Federal Tax Service of the Russian Federation. www.nalog.ru/rn77/about_fts/fts/ structure_fts/mri_fns/ (accessed 15 May 2016).

24 System Obsługi i Wsparcia Podatnika. Koncentracja wyspecjalizowanych urzędów skarbowych na kluczowych podatnikach, Ministerstwo Finansów [Taxpayer Handling and Support System. The Concentration of Specialised Tax Offices on Key Taxpayers], 6, Warsaw 2015, www.warszawa.apodatkowa. gov.pl/c/document_library/get_file?uuid=7fb5f9bd-280b-4d08-9781-53f748b35f27\&groupId=764034 (accessed 15 February 2016).

25 Taxpayers with revenues exceeding an equivalent of Euro $3 \mathrm{~m}$ will be handled by the other 19 STOs.

26 Order of the Ministry of State Revenues of the Republic of Kazakhstan dated April 22, 1999 № 269 On Monitoring of Large Taxpayers.

27 Order of the Government of the Republic of Kazakhstan dated August 14, 2014 № 933 On the Departments of the Central Executive Bodies of the Republic of Kazakbstan, http://adilet.zan.kz/rus/docs/ P1400000933 (accessed 20 November 2014).

28 CTA Strategy (2011:22).

29 CTA (2016:1) Strategy of the Tax Administration for the period 2016-2020, Zagreb, www.poreznauprava.hr/en/Documents/Strategy\%202016-2020\%20final.pdf (accessed 15 February 2017).

30 Regulation on approval and suspension of the special taxpayer status with the aim to advance voluntary tax compliance, Official Gazette, 67/2015.

31 General Tax Act, Article 66 (Official Gazzete, 26/2015).

32 Jaroslaw Marczak, Jasna Bogovac, Rational Tax System in the Light of the Management's Perception a Theoretical Review, in Annales, vol. L, no. 1 (2016), http://cejsh.icm.edu.pl/cejsh/element/bwmeta1. element.ojs-doi-10_17951_h_2016_50_1_421/c/1754-1989.pdf (accessed 15 February 2016). ${ }_{h}$ htp: 2016.50.1.421

33 As well as to the other public administration bodies, since " $(\mathrm{T})$ he public administration in Croatia is more costly than that in many EU Membr States, but does not perform well in terms of effectiveness", European Commission (2016: 24), Country Report Croatia 2016, SWD(2016) 80 final/2, Brussels, ec.europa.eu/ europe2020/pdf/csr2016/cr2016_croatia_en.pdf (accessed 9 May 2017).

34 Ibid.

35 www.financnisprava.cz/en/internation-tax-affairs/news/2015/the-specialized-tax-office-initiateda-n-5762 (accessed 9 May 2016).

36 www.financnisprava.cz/assets/en/attachments/fs-vysledky-cinnosti/vz_fs_2013.pdf (accessed 9 May 2016).

37 The order of the Federal Tax Service of the Russian Federation № MM-3-09/553@ dated 27.09.2007 On Approval of Methodical Instructions to Tax Authorities on Registration of Large Taxpayers that are Russian Organizations, Documents and Commentaries, 2007, № 21.

38 Croatia does not have a long or successful history of the market economy or the substantial inward FDI. This can be supported by the results of international researches showing that "Even with the improvement on the basis of the revised data, Croatia's rank in terms of 'ease of doing business' is still the second lowest in the EU-28 (after Malta)". (EU Commission, SWD(2015) 30 final, Country Report Croatia 2015 (2015: 21, Box 2.1.1). Moreover, "Croatia is the worst performing EU Member State in the OECD product market regulation Index”. Ibid. 21.

39 System Obsługi i Wsparcia Podatnika. Koncentracja wyspecjalizowanych urzędów skarbowych na kluczowych podatnikach, Ministerstwo Finansów [Taxpayer Handling and Support System. The Concentration of Specialised Tax Offices on Key Taxpayers], 5, Warsaw 2015, www.warszawa.apodatkowa. gov.pl/c/document_library/get_file?uuid=7fb5f9bd-280b-4d08-9781-53f748b35f27\&groupId=764034 (accessed 9 May 2016).

40 Key points of the Report of the Accounts Committee on the budget implementation in 2014, http://esep. $\mathrm{kz} / \mathrm{rus} /$ showin/article/2121 (accessed 31 December 2014).

41 Not exactly the real LTO but the Unit for the Large Taxpayers' Audit within the Zagreb Regional Office.

42 OECD mentions 112 employees. See OECD (2015: 93), Tax Administration 2015: Comparative Information on OECD and Other Advanced and Emerging Economies, www.oecd.org/ctp/administration/ tax-administration-23077727.htm (accessed 15 February 2016). 
43 The total number of the large taxpayers is approximately 97,000 of which approximately 53,000 are active taxpayers.

44 State taxes only.

45 Until December 2016. Starting from January 2017 contributions paid by the large taxpayers shall be under responsibility of the LTO.

46 Territorial division only. 